\title{
Uji Infektifitas dan Efektifitas Rhizobia sp. terhadap Tanaman Kedelai di Rumah Kasa pada Tanah Ultisol dengan pH yang Berbeda
}

Infectiveness and Effectiveness Test of Rhizobia sp by Soybean Plant in Screen House on Ultisol Soil with Different $\mathrm{pH}$

M. Reza Alfikri*, Hardy Guchi, Asmarlaili Sahar

Program Studi Agroteknologi, Fakultas Pertanian, Universitas Sumatera Utara, Medan 20155

*Corresponding author : rezaalfikri11@gmail.com

\begin{abstract}
Rhizobia fixed nitrogen from the air and supplied legume and effected to soil fertility. The research was conducted in May 2017 until November at Soil Biology Laboratory and Screen House of Agriculture Faculty University of Sumatera Utara. This research was carried out with 2 stages: growth test at various $p H$ with isolate tested (TJA 1, TJA 2, TJA 3, BGR 1, BGR 2, BGR 3, BGR 4, BALAI 1, BALAI 2, BALAI 3, LP 1, LP 2, LP 3, LP 4 and LAB) and the infectivity test and the effectivity of Rhizobia. The research used Randomized Block Design with 2 treatment: Lime (Without Lime and Lime $1 \times$ Aldd) and Isolate Rhizobia (TJA 1, TJA 3, BGR 1, BGR 3, BGR 4, BALAI 2, BALAI 3, LP 1, LP 2, LP 4 and LAB). The application of Rhizobia's isolate BGR 3 showed the infektively with root nodule amount criteria(124,00). The isolate Rhizobia's BGR 3 effectively increased $N$ plant level and $N$ absorption (3,80 \%; 31,08mg/plant). Application of isolate Rhizobia was not able to increase the level of $P$ plants and $P$ plant uptake. The best interaction was shown (Plant height 85.00 $\mathrm{cm}$, stem diameter $3.93 \mathrm{~mm}$, root nodule 127.50, N level of 3.80\%, $\mathrm{N}$ absorption $30.16 \mathrm{mg}$ / plant) by treatment of BGR 3 and Lime $1 \times$ Aldd.
\end{abstract}

Keywords: $N$ absorption, rhizobia, root nodule, soybean, ultisol soil

\begin{abstract}
ABSTRAK
Rhizobia memiliki peranan penting dalam meningkatkan kesuburan tanah, Rhizobia mampu menyumbangkan nitrogen untuk tanaman dengan cara memfiksasi nitrogen yang ada di udara. Penelitian ini dilakasanakan pada bulan Mei 2017 sampai November 2017 di Laboratorium Biologi Tanah dan Rumah Kasa Fakultas Pertanian Universitas Sumatera Utara. Penelitian ini dilakukan dengan 2 tahap yaitu uji pertumbuhan pada berbagai $\mathrm{pH}$ dengan isolate yang diuji (TJA 1, TJA 2, TJA 3, BGR 1, BGR 2, BGR 3, BGR 4, BALAI 1, BALAI 2, BALAI 3, LP 1, LP 2, LP 3, LP 4 dan LAB) dan uji infektifitas serta efektifitas Rhizobia. Penelitian ini dengan menggunakan metode Rancangan Acak Kelompok dengan 2 faktor perlakuan yaitu Pengapuran (Tanpa Kapur dan Kapur 1 x Aldd) dan Isolat Rhizobia (TJA 1, TJA 3, BGR 1, BGR 3, BGR 4, BALAI 2, BALAI 3, LP 1, LP 2, LP 4 dan LAB). Hasil penelitian menunjukkan bahwa pemberian isolat Rhizobia BGR 3 infektif yang ditandai dengan adanya bintil akar $(124,00)$ dan efektif meningkatkan kadar $\mathrm{N}$ tanaman serta serapan N (3,80\% ; 31,08mg/tanaman ).Pemberian isolate Rhizobia tidak mampu meningkatkan kadar $\mathrm{P}$ tanaman dan serapan $\mathrm{P}$ tanaman. Interaksi terbaik ditunjukkan perlakuan BGR 3 dan Kapur 1 x Aldd (Tinggi tanaman 85,00 cm; diameter batang 3,93 mm; bintil akar 127,50; Kadar N 3,80 \%; serapan N 30,16 mg/tanaman).
\end{abstract}

Kata Kunci : Serapan N, rhizobia, bintil akar, kedelai, tanah ultisol 


\section{PENDAHULUAN}

Produksi kedelai di Indonesia menurut Harnowo (2015) pada tahun 2014 mencapai 954.997 ton. Sementara pada tahun 2015 produksi kedelai mengalami peningkatan yakni mencapai 963.183 ton, hal ini masih jauh dari total kebutuhan kedelai yang mencapai 2,2 juta ton. Produksi kedelai yang masih belum maksimal dikarenakan kondisi lahan yang buruk seperti kesuburan tanah yang rendah.

Permasalahan utama yang menjadikan kedelai tidak mencapai produksi maksimal menurut para

adalah permasalahan

kesuburan tanah. ahli pertanian tingkat umumnya di dominasi tanah Ultisol yang dapat menimbulkan masalah tersendiri dalam pencapaian produktivitas pertanian. Tanah Ultisol dicirikan dengan agregat yang kurang stabil, permeabilitas, bahan organik dan tingkat kebasaan rendah. Disisi lain masalah utama dari tanah ultisol yaitu memiliki tanah yang bersifat masam dengan $\mathrm{pH}$ rata-rata 4,2 - 4,8 dengan tingkat kandungan $\mathrm{Al}$ yang tinggi yakni $>60 \%$ dapat mengakibatkan keracunan pada tanah.

Tanah ultisol memiliki sifat kemasaman yang sangat tinggi. Hal ini ditandai dengan kandungan $\mathrm{Al}$ yang tinggi pada tanah tersebut. Al yang tinggi dapat mengikat $\mathrm{P}$ dan $\mathrm{Mo}$ serta $\mathrm{N}$ menjadi tidak tersedia. Hal ini pula yang menyebabkan mikroorganismee tanah tidak dapat hidup dengan baik seperti Rhizobia sp., maka dari itu perlu diuji isolat Rhizobia sp. yang mampu hidup pada kondisi masam. Pada tanaman kedelai, Rhizobia merupakan urat nadi dalam kegiatan fiksasi nitrogen di udara dan di tanah. Usaha untuk memperbaiki kesuburan tanah ultisol dan meningkatkan produksi kedelai yakni dengan uji potensi Rhizobia. Rhizobia sp dapat membantu proses fiksasi N diudara maupun di tanah, akan tetapi fiksasi
$\mathrm{N}$ tidak aktif apabila kondisi tanah masam dan kandungan $\mathrm{Al}$ yang tinggi

Berdasarkan penelitian Hanafiah (2009) Rhizobium tidak dapat hidup $\mathrm{pH} \leq 4,3$. Sebab bakteri yang berperan dalam proses fiksasi $\mathrm{N}$ ini peka terhadap kemasaman, hal ini jelas dapat mempengaruhi kebutuhan $\mathrm{N}$ tanaman. Berdasarkan yang dilakukan

Widyasari et al (2013) mengenai pengaruh pH media terhadap ketahanan Rhizobia sp menunjukkan bahwa kemapuan bakteri Rhizobia sp yang dikondisikan pertumbuhannya dengan $\mathrm{pH}$ 5,8 lebih resisten dan mampu beradaptasi terhadap kondisi asam dibandingkan dengan Rhizobia sp. yang dikondisikan pertumbuhannya dengan $\mathrm{pH}$ 7,0.Berdasarkan penelitian yang dilakukan Niste et al (2013) menyatakan bakteri Rhizobium trifolii tumbuh baik dan berkembang pada $\mathrm{pH}$ 8,0 yang ditandai dengan jumlah populasi dari bakteri tersebut yaitu 6253,33 CFU yang dibandingkan dengan $\mathrm{pH} 5,0 ; 6,0$; dan 7,0. Untuk itu perlu dilakukan pengujian ulang terhadap pertumbuhan Rhizobia sp. pada berbagai kondisi $\mathrm{pH}$ dan $\mathrm{Al}$ sehingga dapat diperoleh kondisi optimum untuk pertumbuhan Rhizobia sp.

Berdasarkan uraian diatas peneliti tertarik untuk melakukan penelitian yang berjudul Uji Infektifitas dan Efektifitas Rhizobia sp. terhadap Tanaman Kedelai di Rumah Kasa pada Tanah Ultisol dengan $\mathrm{pH}$ yang Berbeda.

\section{BAHAN DAN METODE}

Penelitian ini telah dilaksanakan di Rumah Kasa dan Laboratorium Biologi Tanah pada bulan Mei 2017 sampai dengan November 2017.

Bahan yang digunakan dalam penelitian ini adalah benih kedelai var. Anjasmoro, tanah ultisol, $\left(\mathrm{CaMg}\left(\mathrm{CO}_{3}\right)_{2}\right)$, polibag, pupuk kimia lengkap, isolat Rhizobia, bahan kimia untuk pembuatan 
media (Yeast Extract Mannitol) serta bahan lain yang digunakan pada percobaan ini

Alat yang digunakan dalam penelitian ini adalah bor tanah, meteran, timbangan, ayakan tanah 10 mesh, GPS (Global Positioning System), LAF (Laminar Air Flow), autoklaf, tabung reaksi (testtube), gelas beaker, erlenmeyer, jarum suntik serta alat lain yang digunakan untuk percobaan ini.

Penelitian ini menggunakan 3 tahap penelitian : 1. Isolasi dan purifikasi Rhizobia sp dari bintil akar tanaman kedelai. 2. Uji Pertumbuhan Rhizobia pada berbagai kondisi pH. 3. Uji infektifitas dan Efektifitas Rhizobia pada terhadap tanaman kedelai di rumah kasa pada tanah ultisol dengan $\mathrm{pH}$ yang berbeda dengan metode Rancangan Acak Kelompok (RAK) dengan 2 faktor yang terdiri atas: Pengapuran (tanpa kapur (0 ton/ha), setara $1 \mathrm{x}$ Aldd dan, Isolat Rhizobia (TJA 1, BGR 1, BALAI 3, LAB, LP 1, LP 4, TJA 3, LP 2, BGR 3, BALAI 2, BGR 4). Data yang diperoleh dianalisis secara statistik berdasarkan analisis varian pada setiap peubah amatan yang diukur dan diuji lanjut bagi perlakuan yang nyata dengan menggunakan uji beda Duncan Multiple Range Test pada taraf 5\%.

\section{HASIL DAN PEMBAHASAN}

\section{pH Tanah Setelah Inkubasi Kapur}

Hasil pengukuran $\mathrm{pH}$ tanah tanah setelah inkubasi kapur dolomite dapat dilihat pada Tabel 1:

Pemberian kapur dolomit dengan dosis $1 \times$ Aldd dapat meningkatkan $\mathrm{pH}$ tanah secara nyata. Pemebrian kapur dolomit $1 \mathrm{x}$
Aldd meningkatkan $\mathrm{pH}$ tanah tertinggi $(5,5)$ jika dibandingkan dengan tanpa pemberian kapur dolomit $(4,94)$.

Pemberian kapir dolomit dengan dosis $1 \mathrm{x}$ Aldd dapat meningkatkan $\mathrm{pH}$ tanah dikarenakan fungsi utama dari kapur dapat mengendapkan $\mathrm{Al}$ yang terdapat di dalam tanah yang menyebabkan tanah masam. Selain itu, kapur dolomit yang mengandung $\mathrm{Ca}$ dan $\mathrm{Mg}$ dapat menyumbangkan ion-ion basa dalam tanah dan emampu menggantikan Al yang berada didalam koloid tanah. Hal ini didukung oleh pernyataan Soepardi (1983) yang menyatakan bahwa tujuan pemberian kapur ke dalam tanah ialah untuk mengurangi atau meniadakan $\mathrm{Al}$ di dalam tanah sehingga $\mathrm{pH}$ tanah dapat meningkat.

Pemberian kapur dolomit pada lahan pertanian secara berlebihan dapat berakibat negative pada lahan tersebut. Pemberian kapur pada tanah secara berlebihan dapat mengakibatkan unsur hara $\mathrm{P}$ akan terjerap di dalam tanah. Selain hara $\mathrm{P}$ yang terjerap di dalam tanah mengakibatkan $\mathrm{Ca}$ dan $\mathrm{Mg}$ menjadi berlebih di dalam tanah sehingga mengakibatkan hara hara utama lainnya menjadi terejerap maupun terikat di dalam tanah oleh ion ion yang ada didalam tanah.

Pemberian kapur dolomit pada tanah selain dapat meningkatkan $\mathrm{pH}$ tanah, kapur tersebut dapat berepengaruh terhadap pertumbuhan bakteri Rhizobia. Semakin tinggi $\mathrm{pH}$ tanah maka pertumbuhan bakteri Rhizobia akan semakin baik dikarenakan bakteri tersebut baik pertumbuhannya pada $\mathrm{pH}$ yang basa.

Tabel 1.pH Tanah Setelah Inkubasi Kapur

PERLAKUAN

pH Tanah

\begin{tabular}{lc}
\hline $\mathrm{K}_{0}$ (Tanpa Kapur) & $4,94 \mathrm{~b}$ \\
$\mathrm{~K}_{1}($ Kapur 1 x Aldd) & $5,5 \mathrm{a}$ \\
\hline \multicolumn{1}{c}{ RATAAN } & 5,22 \\
\hline
\end{tabular}


Keterangan : Angka yang diikuti oleh huruf yang sama tidak berbeda nyata pada taraf $\alpha$ 5\% menurut uji Duncan Multiple Range Test. 


\section{Populasi Bakteri Rhizobia Pada Media YEM Cair}

Hasil pengujian bakteri Rhizobia pada pH media YEM yang berbeda dapat dilihat nilai rataan populasi bakteri Rhizobia pada Tabel 2 dibawah ini:

Tabel 2. Populasi Bakteri Rhizobia Pada Media YEM Cair

\begin{tabular}{|c|c|c|c|c|c|c|c|c|c|}
\hline \multicolumn{10}{|c|}{ POPULASI BAKTERI RHIZOBIA } \\
\hline $\begin{array}{c}\text { KODE } \\
\text { ISOLAT }\end{array}$ & \multicolumn{9}{|c|}{$\mathrm{pH}$} \\
\hline TJA 1 & $1,45 \times 10^{8}$ & $4,27 \times 10^{8}$ & $5,41 \times 10^{8}$ & $7,59 \times 10^{8}$ & $12,48 \times 10^{8}$ & $12,49 \times 10^{8}$ & $23,99 \times 10^{8}$ & $12,57 \times 10^{8}$ & $17,24 \times 10^{8}$ \\
\hline TJA 3 & $2,54 \times 10^{8}$ & $3,32 \times 10^{8}$ & $5,59 \times 10^{8}$ & $15,96 \times 10^{8}$ & $20,42 \times 10^{8}$ & $25,94 \times 10^{8}$ & $31,98 \times 10^{8}$ & $37,79 \times 10^{8}$ & $45,73 \times 10^{8}$ \\
\hline LP 1 & $3,27 \times 10^{8}$ & $3,06 \times 10^{8}$ & $5,25 \times 10^{8}$ & $16,63 \times 10^{8}$ & $13,39 \times 10^{8}$ & $9,61 \times 10^{8}$ & $26,63 \times 10^{8}$ & $34,63 \times 10^{8}$ & $40,17 \times 10^{8}$ \\
\hline LP 3 & $1,84 \times 10^{6}$ & $4,55 \times 10^{6}$ & $5,15 \times 10^{6}$ & $8,31 \times 10^{6}$ & $12,54 \times 10^{6}$ & $12,47 \times 10^{6}$ & $10,32 \times 10^{6}$ & $13,90 \times 10^{6}$ & $16,91 \times 10^{6}$ \\
\hline LP 4 & $8,62 \times 10^{8}$ & $14,77 \times 10^{8}$ & $12,69 \times 10^{8}$ & $13,76 \times 10^{8}$ & $26,32 \times 10^{8}$ & $15,64 \times 10^{8}$ & $37,02 \times 10^{8}$ & $32,94 \times 10^{8}$ & $37,13 \times 10^{8}$ \\
\hline BGR 1 & $9,1 \times 10^{7}$ & $7,53 \times 10^{7}$ & $1,767 \times 10^{8}$ & $3 \times 10^{8}$ & $16,3 \times 10^{8}$ & $16,6 \times 10^{8}$ & $34,9 \times 10^{8}$ & $27,45 \times 10^{8}$ & $27,26 \times 10^{8}$ \\
\hline BGR 2 & $2,52 \times 10^{6}$ & $3,61 \times 10^{6}$ & $5,3 \times 10^{6}$ & $9,14 \times 10^{6}$ & $10,88 \times 10^{6}$ & $14,57 \times 10^{6}$ & $17,3 \times 10^{6}$ & $23,16 \times 10^{6}$ & $26,91 \times 10^{6}$ \\
\hline BALAI 2 & $3,51 \times 10^{8}$ & $9,54 \times 10^{8}$ & $10,34 \times 10^{8}$ & $12,91 \times 10^{8}$ & $12,68 \times 10^{8}$ & $23,02 \times 10^{8}$ & $17,68 \times 10^{8}$ & $34,19 \times 10^{8}$ & $38,75 \times 10^{8}$ \\
\hline BALAI 3 & $3,57 \times 10^{8}$ & $3,38 \times 10^{8}$ & $5,25 \times 10^{8}$ & $16 \times 10^{8}$ & $20,18 \times 10^{8}$ & $27,27 \times 10^{8}$ & $32,35 \times 10^{8}$ & $38,23 \times 10^{8}$ & $43,47 \times 10^{8}$ \\
\hline
\end{tabular}




\begin{tabular}{|c|c|c|c|c|c|c|c|c|}
\hline LAB & $1,16 \times 10^{8}$ & $2,35 \times 10^{8}$ & $2,97 \times 10^{8}$ & $10,16 \times 10^{8}$ & $20,20 \times 10^{8}$ & $24,66 \times 10^{8}$ & $32,50 \times 10^{8}$ & $36,82 \times 10^{8}$ \\
\hline
\end{tabular}


Berdasarkan data yang ditampilkan pada Tabel 2 tampak bahwa tidak semua isolat Rhizobia mampu hidup pada kondisi pH 3, seperti isolat TJA 2, BGR 2, BALAI 1 dan LP 3 dengan nilai populasi Rhizobia berturut-turut $0,83 \times 10^{6}, 2,52 \times 10^{6}, 12,54$ x $10^{6}$ dan $1,84 \times 10^{6}$. Berbeda dengan isolat Rhizobia TJA 1, TJA 3, BGR 1, BGR 3, BGR 4, BALAI 2, BALAI 3, LP 1, LP 2, LP 4 dan LAB yang mampu hidup lebih besar dari isolat lain dengan nilai populasi Rhizobia berturut-turut $1,45 \mathrm{x}$ $10^{8}, 2,54 \times 10^{8}, 9,1 \times 10^{7}, 8,28 \times 10^{8}, 1.52$ $\mathrm{x} 10^{8}, 3,51 \times 10^{8}, 3,57 \times 10^{8}, 3,27 \times 10^{8}$, $3,49 \times 10^{8}, 8,62 \times 10^{8}$ dan $1,16 \times 10^{8}$.

Berdasarkan data yang ditampilkan pada Tabel 2 tampak bahwa semakin tinggi $\mathrm{pH}$ media maka semakin tinggi pula populasi pertumbuhan Rhizobia. Seperti hal nya ditunjukkan pada isolat I9 pada perlakuan $\mathrm{P}_{1}$ populasi Rhizobia lebih kecil dari $\mathrm{P}_{2}<\mathrm{P}_{3}<\mathrm{P}_{4}<\mathrm{P}_{5}<\mathrm{P}_{6}<\mathrm{P}_{7}<\mathrm{P}_{8}<\mathrm{P}_{9}$ dengan nilai populasi berturut-turut $8,28 \mathrm{x}$ $10^{8}, 14,52 \times 10^{8}, 13,04 \times 10^{8}, 14,17 \times 10^{8}$, $26,31 \times 10^{8}, 15,69 \times 10^{8}, 37,02 \times 10^{8}, 34,5$ x $10^{8}$ dan $45,17 \times 10^{8}$.

Berdasarkan data yang ditampilkan pada Tabel 2 tampak bahwa tidak semua bakteri tumbuh baik pada berbagai kondisi $\mathrm{pH}$, maka dari itu untuk pengujian lanjut infektifitas dan efektifitas bakteri Rhizobia hanya berbagai isolat saja yang diuji lanjutan. Isolat yang di uji lanjut infektivitas dan efektifitas Rhizobia dengan kode isolat TJA 1, TJA 3, BGR 1, BGR 3, BGR 4, BALAI 2, BALAI 3, LP 1, LP 2, LP 4 dan LAB.

\section{Tinggi Tanaman Kedelai}

Hasil pengukuran tinggi tanaman kedelai dapat dilihat pada tabel di bawah ini

Berdasarkan data yang ditampilkan pada Tabel 3 tampak bahwa pemberian kapur dan isolat bakteri Rhizobia tidak jauh berbeda pada setiap perlakuannya, namun dapat meningkatkan pertumbuhan tanamannya. Pada perlakuan pemberian kapur 1 x Aldd $(69,23)$ lebih tinggi dibandingkan dengan perlakuan tanpa diberi kapur. Hal ini dikarenakan tanaman kedelai membutuhkan kondisi $\mathrm{pH}$ optimum untuk pertumbuhan tanamannya. Kondisi optimum untuk pertumbuhan tanaman kedelai sekitar $\mathrm{pH} 5-5,5$.

Tabel 3. Tinggi Tanaman Kedelai (Glycine max L.)

\begin{tabular}{|c|c|c|c|}
\hline \multicolumn{4}{|c|}{ TINGGI TANAMAN (cm) } \\
\hline \multirow{2}{*}{ ISOLAT } & \multicolumn{2}{|c|}{ PENGAPURAN } & \multirow{2}{*}{ RATAAN } \\
\hline & $\mathrm{K}_{0}$ (Tanpa Kapur) & $\mathrm{K}_{1}$ (Kapur 1 x Aldd) & \\
\hline $\mathrm{I}_{0}$ (Kontrol) & 60,50 & 51,75 & 56,13 \\
\hline $\mathrm{I}_{1}$ (TJA 1) & 59,25 & 74,25 & 66,75 \\
\hline $\mathrm{I}_{2}(\mathrm{BGR} 1)$ & 62,50 & 69,00 & 65,75 \\
\hline $\mathrm{I}_{3}(\mathrm{BALAI} 3)$ & 68,75 & 74,00 & 71,38 \\
\hline $\mathrm{I}_{4}(\mathrm{LAB})$ & 70,65 & 71,50 & 71,08 \\
\hline $\mathrm{I}_{5}(\mathrm{LP} 1)$ & 62,25 & 74,50 & 68,38 \\
\hline $\mathrm{I}_{6}(\mathrm{LP} 4)$ & 67,25 & 62,15 & 64,70 \\
\hline I7 (TJA 3) & 72,00 & 70,50 & 71,25 \\
\hline $\mathrm{I}_{8}$ (LP 2) & 69,50 & 67,00 & 68,25 \\
\hline $\mathrm{I}_{9}$ (BGR 3) & 71,25 & 85,00 & 78,13 \\
\hline I10 (BALAI 2) & 61,50 & 63,15 & 62,33 \\
\hline $\mathrm{I}_{11}$ (BGR 4) & 79,50 & 68,00 & 73,75 \\
\hline RATAAN & 67,08 & 69,23 & \\
\hline
\end{tabular}


Keterangan : Angka yang diikuti oleh huruf yang sama tidak berbeda nyata pada taraf $\alpha$ 5\% menurut uji Duncan Multiple Range Test

Pemberian isolat Rhizobia pada tanaman kedelai tidak menunjukkan pertambahan tinggi tanaman yang tinggi, akan tetapi pemberian isolat Rhizobia pada perlakuan I9 (BGR 3) $(78,13)$ lebih tinggi dibandingkan dengan tanpa pemberian isolat Rhizobia $\mathrm{I}_{0}$ (Kontrol) $(56,13)$. Hal ini dikarenakan pemberian isolat Rhizobia tidak berupa taraf dosis pen ingkatan melainkan dengan taraf dosis yag sama dan populasi Rhizobia yang seimbang.

Pada perlakuan Isolat Rhizobia jauh lebih tinggi pada perlakuan $\mathrm{K}_{1}$ (kapur 1 x Aldd) $(69,23)$ dibandingkan dengan $\mathrm{K}_{0}$ (tanpa kapur) $(67,08)$. Hal ini dikarenakan Bakteri Rhizobia lebih optimum berkembang pada $\mathrm{pH}$ yang lebih tinggi/netral hingga basa jika dibandingkan pada $\mathrm{pH}$ tanah yang masam. Hal ini di dukung oleh pernyataan Purwaningsih (2008) yang menyatakan bahwa faktor yang mempengaruhi bakteri Rhizobia didalam tanah yaitu kelembaban, $\mathrm{pH}$ tanah serta tingkat ketahanan bakteri tersebut.

\section{Diameter Batang}

Tabel 4. Diameter Batang Tanaman Kedelai (Glycine max L.)

\begin{tabular}{|c|c|c|c|}
\hline \multicolumn{4}{|c|}{ DIAMETER BATANG (mm) } \\
\hline \multirow{2}{*}{ ISOLAT } & \multicolumn{2}{|c|}{ PENGAPURAN } & \multirow{2}{*}{ RATAAN } \\
\hline & $\mathrm{K}_{0}$ (Tanpa Kapur) & $\mathrm{K}_{1}$ (Kapur 1 x Aldd) & \\
\hline $\mathrm{I}_{0}$ (Kontrol) & 2,28 & 2,83 & 2,55 \\
\hline I1 (TJA 1) & 3,11 & 3,45 & 3,28 \\
\hline $\mathrm{I}_{2}(\mathrm{BGR} 1)$ & 2,95 & 3,22 & 3,08 \\
\hline $\mathrm{I}_{3}$ (BALAI 3) & 3.01 & 3,81 & 3,41 \\
\hline $\mathrm{I}_{4}(\mathrm{LAB})$ & 3,15 & 3,64 & 3,39 \\
\hline $\mathrm{I}_{5}(\mathrm{LP} 1)$ & 2,75 & 3,72 & 3,23 \\
\hline $\mathrm{I}_{6}(\mathrm{LP} 4)$ & 3,29 & 3,68 & 3,49 \\
\hline $\mathrm{I}_{7}$ (TJA 3) & 3,13 & 3,42 & 3,28 \\
\hline $\mathrm{I}_{8}$ (LP 2) & 3,00 & 3,42 & 3,21 \\
\hline $\mathrm{I}_{9}(\mathrm{BGR} 3)$ & 2,96 & 3,93 & 3,44 \\
\hline $\mathrm{I}_{10}(\mathrm{BALAI} 2)$ & 3,18 & 2,85 & 3,01 \\
\hline
\end{tabular}

Hasil pengukuran diameter batang kedelai dapat dilihat pada tabel dibawah ini:.

Berdasarkan hasil pengukuran diameter batang yang ditampilkan pada Tabel 3 diketahui diameter batang kedelai berpengaruh nyata terhadap pemberian kapur. Perlakuan $\mathrm{K}_{1}$ (Kapur 1 x Aldd) sebesar 3,41 lebih tinggi dibandingkan dengan $\mathrm{K}_{0}$ (tanpa kapur) sebesar 3,02. Pada perlakuan isolat Rhizobia diameter batang tidak berpengaruh nyata terhadap peningkatan diameter batang. Pemberian isolate dapat meningkatkan pertambahan diameter batang. Hal ini dikarenakan Rhizobia tidak begitu efektif dalam peningkatan diameter batang.

Pada perlakuan isolat Rhizobia, perlakuan I9 (BGR 3) dan I6 ( LP 4) lebih tinggi sebesar 3,44 dan 3,49 dibandingkan dengan $\mathrm{I}_{0}$ (control) sebesar 2,55. Pemberian isolat Rhizobia tidak begitu nyata terhadap peningkatan diameter batang akan tetapi terlihat peningkatan yang signifikan jika dibandingkan dengan diberikan isolat Rhizobia dan tanpa isolat Rhizobia. Namun demikian, pemberian isolate Rhizobia tidak dapat meningkatkan pertambahan diameter batang secara nyata. 


\begin{tabular}{clll}
\hline $\mathrm{I}_{11}$ (BGR 4) & 3,46 & 2,92 & 3,19 \\
\hline RATAAN & $3,02 \mathrm{~b}$ & $3,41 \mathrm{a}$ & \\
\hline
\end{tabular}

Keterangan : Angka yang diikuti oleh huruf yang sama tidak berbeda nyata pada taraf $\alpha 5 \%$ menurut uji Duncan Multiple Range Test

Pemberian isolat Rhizobia serta pengapuran mengahasilkan hasil yang lebih baik jika dibandingkan dengan tanpa isolat Rhizobia dan tanpa kapur. Penggunaan isolat Rhizobia yang efektif dapat meningkatkan pertumbuhan tanaman dengan baik. Hal ini sesuai dengan pernyataan Yuwono (2006) yang menyatakan bahwa bakteri Bradyrhizobium dapat meningkatkan pertumbuhan tanaman dengan hasil yang tidak begitu signifikan dikarenakan lamanya perkembangan bakteri dalam memfiksasi $\mathrm{N}$ serta penyebaran hara ke jaringan tanaman.

\section{Jumlah Bintil Akar}

Hasil pengukuran jumlah bintil akar dapat dilihat pada tabel di bawah ini :

Berdasarkan hasil pengukuran jumlah bintil akar yang ditampilkan pada Tabel 5 diketahui jumlah bintil akar tertinggi ditunjukkan pada pemberian isolat BGR 3 dengan pemberian kapur $1 \mathrm{x}$ Aldd ( $\left.\mathrm{K}_{1} \mathrm{I}_{9}\right)$ yaitu 127,50 dan jumlah bintil akar terendah ditunjukkan oleh perlakuan tanpa isolat Rhizobia dan tanpa kapur
(Kontrol) $\left(\mathrm{K}_{0} \mathrm{I}_{0}\right)$ yaitu 18,50. Perlakuan $\mathrm{K}_{1} \mathrm{I}_{9}$ tidak berbeda nyata dengan perlakuan $\mathrm{K}_{0} \mathrm{I}_{9}, \mathrm{~K}_{1} \mathrm{I}_{4}, \mathrm{~K}_{0} \mathrm{I}_{7}, \mathrm{~K}_{1} \mathrm{I}_{10}, \mathrm{~K}_{0} \mathrm{I}_{6}, \mathrm{~K}_{1} \mathrm{I}_{1} ， \mathrm{~K}_{0} \mathrm{I}_{3}$, $\mathrm{K}_{1} \mathrm{I}_{8}$ dan $\mathrm{K}_{1} \mathrm{I}_{5}$ serta berbeda nyata dengan $\mathrm{K}_{1} \mathrm{I}_{3}, \mathrm{~K}_{1} \mathrm{I}_{11}, \mathrm{~K}_{0} \mathrm{I}_{10}, \mathrm{~K}_{0} \mathrm{I}_{5}, \mathrm{~K}_{1} \mathrm{I}_{6}, \mathrm{~K}_{0} \mathrm{I}_{4}, \mathrm{~K}_{0} \mathrm{I}_{11}$, $\mathrm{K}_{1} \mathrm{I}_{2}, \mathrm{~K}_{0} \mathrm{I}_{8}, \mathrm{~K}_{1} \mathrm{I}_{7}, \mathrm{~K}_{0} \mathrm{I}_{2}, \mathrm{~K}_{0} \mathrm{I}_{1}, \mathrm{~K}_{1} \mathrm{I}_{0}$ dan $\mathrm{K} 0 \mathrm{I} 0$. Isolat Rhizobia mampu meningkatkan jumlah bintil akar dengan jenis isolat terbaik yaitu I9 (BGR 3) dimana nilai rataan jumlah bintil akar yang didapat yaitu 124,00 yang lebih tinggi jika dibandingkan dengan tanpa pemberian isolat Rhizobia (I0). Pemberian isolat I9 berpengaruh sangat nyata terhadap perlakuan Isolat Rhizobia yang lain. Hal ini dikarenakan tingkat pembentukan bintil akar tergantung terhadap kemampuan bakteri tersebut menginfeksi akar tanaman. Infektivitas tanaman kedelai dapat ditandai dengan adanya bintil akar pada tanaman tersebut. Nilai infektifitas tanaman kedelai tergantung terhadap kemampuan bakteri Rhizobia dalam menginfeksi akar tanaman tersebut. Semakin banyak bintil akar pada tanaman maka nilai infektifitasnya semakin tinggi terhadap tanaman tersebut.

Tabel 5. Jumlah Bintil Akar Tanaman Kedelai (Glycine max L.)

\begin{tabular}{|c|c|c|c|}
\hline \multicolumn{4}{|c|}{ JUMLAH BINTIL AKAR } \\
\hline \multirow{2}{*}{ ISOLAT } & \multicolumn{2}{|c|}{ PENGAPURAN } & \multirow{2}{*}{ RATAAN } \\
\hline & $\mathrm{K}_{0}$ (Tanpa Kapur) & $\mathrm{K}_{1}$ (Kapur 1 x Aldd) & \\
\hline $\mathrm{I}_{0}$ (Kontrol) & $18,50 \mathrm{i}$ & 34,00hi & $26,25 d$ \\
\hline $\mathrm{I}_{1}$ (TJA 1) & $56,00 \mathrm{gh}$ & 99,00abcd & $77,50 \mathrm{bc}$ \\
\hline $\mathrm{I}_{2}(\mathrm{BGR} 1)$ & $59,50 f g h$ & $70,50 \mathrm{cdefg}$ & $65,00 \mathrm{c}$ \\
\hline $\mathrm{I}_{3}(\mathrm{BALAI} 3)$ & $95,00 \mathrm{abcde}$ & $91,00 \mathrm{bcdef}$ & $93,00 b$ \\
\hline $\mathrm{I}_{4}(\mathrm{LAB})$ & $72,50 \mathrm{cdefg}$ & $103,00 \mathrm{abc}$ & $87,75 b c$ \\
\hline I5 (LP 1) & $86,00 \mathrm{bcdefg}$ & 92,50abcdef & $89,25 b$ \\
\hline $\mathrm{I}_{6}(\mathrm{LP} 4)$ & $100,00 \mathrm{abcd}$ & 83,50 cdefg & $91,75 b$ \\
\hline I7 (TJA 3) & $102,00 \mathrm{abc}$ & $63,00 \mathrm{efgh}$ & $82,50 \mathrm{bc}$ \\
\hline $\mathrm{I}_{8}$ (LP 2) & $66,00 \mathrm{defgh}$ & $92,50 \mathrm{abcdef}$ & $79,25 b c$ \\
\hline $\mathrm{I}_{9}$ (BGR 3) & $120,50 \mathrm{ab}$ & $127,50 \mathrm{a}$ & $124,00 \mathrm{a}$ \\
\hline
\end{tabular}




\begin{tabular}{clll}
\hline $\mathrm{I}_{10}($ BALAI 2) & $86,50 \mathrm{bcdefg}$ & $100,50 \mathrm{abcd}$ & $93,50 \mathrm{~b}$ \\
$\mathrm{I}_{11}$ (BGR 4) & $71,50 \mathrm{cdefg}$ & $90,00 \mathrm{bcdefg}$ & $80,75 \mathrm{bc}$ \\
\hline RATAAN & $77,83 \mathrm{~b}$ & $87.25 \mathrm{a}$ & \\
\hline
\end{tabular}

Keterangan : Angka yang diikuti oleh huruf yang sama tidak berbeda nyata pada taraf $\alpha 5 \%$ menurut uji Duncan Multiple Range Test

Pada perlakuan pemberian isolat Rhizobia, terlihat bahwa seluruh bakteri mampu meninfeksi akar tanaman dengan ditunjukkan terhadap ada tidaknya bintil akar pada suatu tanaman. Tingkat infektivitas Rhizobia dapat dilihat dari jumlah bintil akar yang terbentuk dimana semakin banyak bintil akar yang terbentuk maka semakin tinggi pula nilai infektivitasnya. Rendahnya tingkat infektivitas Rhizobia dipengaruhi oleh ketahanan bakteri, $\mathrm{pH}$ yang menghambat perkembangan Rhizobia, Rhizobia yang kurang adatif terhadap perbedaan $\mathrm{pH}$ dapat mengakibatkan bakteri tidak mampu berkembang. Hal ini sesuai dengan pernyataan Hanafiah (1991) yang menyatakan faktor yang mempengaruhi pembentukan bintil akar dapat berupa lingkungan seperti $\mathrm{pH}$ dan ketersediaan hara.

Pemberian kapur dolomit pada tanah mampu meningkatkan jumlah bintil akar dimana pada perlakuan pemberian kapur 1 x Aldd $\left(\mathrm{K}_{1}\right)$ yaitu 87,25 lebih tinggi dibandingkan dengan tanpa pemberian kapur $\left(\mathrm{K}_{0}\right)$ yaitu 77,83 . Hal ini dikarenakan semakin tinggi $\mathrm{pH}$ tanah maka semakin baik pula pertumbuhan bakteri dan bintil akar terbentuk dengan baik. Jika $\mathrm{pH}$ tanah masam maka bakteri tidak mampu baik untuk menginfeksi akar tanaman. Selain itu, penggunaan isolat yang mampu hidup di tanah $\mathrm{pH}$ yang masam akan mampu menginfeksi akar dengan baik akan tetapi isolat tersebut jauh lebih baik jika hidup pada $\mathrm{pH}$ yang basa. Hal ini didukung oleh Hanafiah (2009) Rhizobium tidak dapat hidup $\mathrm{pH} \leq 4,3$. Sebab bakteri yang berperan dalam proses fiksasi $\mathrm{N}$ ini peka terhadap kemasaman.

\section{Berat Kering Tajuk}

Hasil pengukuran berat kering tanjuk tanaman kedelai dapat dilihat pada tabel di bawah ini :

Berdasarkan data yang ditampilkan pada Tabel 6 tampak bahwa berat kering tajuk tidak jauh berbeda pada setiap perlakuannya, namun terdapat peningkatan berat kering tajuk jika dibandingkan dengan perlakuan kontrol. Pada perlakuan $\mathrm{K}_{1}$ (kapur 1xAldd) yaitu 6,45 lebih tinggi dibandingkan dengan perlakuan $\mathrm{K}_{0}$ (tanpa kapur). Hal ini dikarenakan $\mathrm{pH}$ tanah pada perlakuan tersebut optimum untuk pertumbuhan tanaman kedelai.

Tabel 6. Berat Kering Tajuk Tanaman Kedelai (Glycine max L.)

\begin{tabular}{lccc}
\hline \multicolumn{3}{c}{ BERAT KERING TAJUK $(\mathrm{g})$} \\
\hline \multirow{2}{*}{ ISOLAT } & \multicolumn{2}{c}{ PENGAPURAN } & \multirow{2}{*}{ RATAAN } \\
\cline { 2 - 3 } & $\mathrm{K}_{0}$ (Tanpa Kapur) & $\mathrm{K}_{1}$ (Kapur 1 x Aldd) & \\
\hline I0 $_{0}$ (Kontrol) & 3,11 & 3,25 & 3,18 \\
I $_{1}$ (TJA 1) & 6,17 & 8,39 & 7,28 \\
I $_{2}$ (BGR 1) & 6,59 & 5,21 & 5,90 \\
I $_{3}$ (BALAI 3) & 6,49 & 7,82 & 7,15 \\
I $_{4}$ (LAB) & 6,50 & 7,81 & 7,15 \\
I5 $_{5}$ (LP 1) & 4,63 & 9,80 & 7,21 \\
I6 $_{6}$ (LP 4) & 7,63 & 6,37 & 7,00
\end{tabular}




\begin{tabular}{llll} 
I7 (TJA 3) & 5,01 & 5,20 & 5,10 \\
I $_{8}$ (LP 2) & 8,01 & 5,55 & 6,78 \\
I $_{9}$ (BGR 3) & 8,34 & 7,93 & 8,13 \\
I $_{10}$ (BALAI 2) & 6,33 & 4,63 & 5,48 \\
I $_{11}$ (BGR 4) & 7,47 & 5,43 & 6,45 \\
\hline \multicolumn{1}{c}{ RATAAN } & 6,35 & 6,45 & \\
\hline
\end{tabular}

Keterangan : Angka yang diikuti oleh huruf yang sama tidak berbeda nyata pada taraf $\alpha 5 \%$ menurut uji Duncan Multiple Range Test

Pemberian isolat Rhizobia yang

berbeda menunjukkan berat kering tajuk yang tidak berbeda nyata secara statistic. Hal ini berkaitan dengan tingkat efektifitas bakteri tersebut dalam menambat $\mathrm{N}$ diudara. Tingkat efektifitas bakteri Rhizobia berkaitan dengan faktor lingkungan seperti $\mathrm{pH}$ tanah serta kandungan hara yang ada didalam tanah. Selain itu, Rhizobia yang terdapat pada bintil akar belum efektif secara sempurna dalam menambat $\mathrm{N}$ diudara. Hal ini didukung oleh Purwaningasih (2008) yang menyatakan bahwa faktor yang berpengaruh pada proses fiksasi nitrogen terdapatnya tanaman inang yang sesuai, $\mathrm{pH}$ tanah, ketersediaan hara serta adanya serangan virus bakteri (bacteriophage) dapat menyebabkan berkurangnya populasi Rhizobia dalam tanah.

Pemberian isolat Rhizobia I9 (BGR 3) yaitu 8,13 lebih tinggi dibandingkan kontrol (tanpa isolat) yaitu 3,18 . Selain itu, pemberian isolat BGR 3 lebih tinggi meningkatkan berat kering tajuk dibandingkan dengan isolat lain walapun tidak jauh berbeda nyata dalam statistic.

\section{Kadar N}

Hasil pengukuran kadar $\mathrm{N}$ tanaman kedelai dapat dilihat pada tabel di bawah ini :

Isolat Rhizobia mampu meningkatkan kadar $\mathrm{N}$ tanaman dengan jenis isolat terbaik I9 (BGR 3), dimana rataan kadar $\mathrm{N}$ yang didapat yaitu 3,80 yang lebih tinggi $102 \%$ jika dibandingkan dengan tanpa isolat Rhizobia ( $\mathrm{I}_{0}$ ). Pemberian isolat Rhizobia pada tanaman mampu meningkatkan kadar $\mathrm{N}$ tanaman dikarenakan bakteri Rhizobia telah menginfeksi akar tanaman dan membentuk bintil akar sehingga mampu memfiksasi nitrogen yang ada di udara sebesar $70 \%$ lebih. Hal ini didukung oleh Surtiningsih, et al, (2009) yang menyatakan terbentuknya bintil akar efektif yang lebih banyak mampu meningkatkan penambatan nitrogen yang selanjutnya untuk membentuk klorofil dan enzim. Peningkatan klorofil dan enzim mampu meningkatkan fotosintesis yang pada akhirnya dapat meningkatkan pertumbuhan vegetatif dan generatif (hasil produksi biji) tanaman.

Tabel 7. Kadar N Tanaman Kedelai (Glycine max L.)

\begin{tabular}{|c|c|c|c|}
\hline \multicolumn{4}{|c|}{ KADAR N (\%) } \\
\hline \multirow{2}{*}{ ISOLAT } & \multicolumn{2}{|c|}{ PENGAPURAN } & \multirow{2}{*}{ RATAAN } \\
\hline & $\mathrm{K}_{0}$ (Tanpa Kapur) & $\mathrm{K}_{1}$ (Kapur 1 x Aldd) & \\
\hline $\mathrm{I}_{0}$ (Kontrol) & 1,67 & 2,09 & $1,88 \mathrm{e}$ \\
\hline $\mathrm{I}_{1}(\mathrm{TJA} 1)$ & 3,10 & 3,56 & $3,33 b c$ \\
\hline $\mathrm{I}_{2}(\mathrm{BGR} 1)$ & 3,15 & 3,55 & $3,35 b c$ \\
\hline $\mathrm{I}_{3}$ (BALAI 3$)$ & 3,16 & 2,53 & $2,85 \mathrm{~d}$ \\
\hline $\mathrm{I}_{4}(\mathrm{LAB})$ & 3,06 & 3,34 & $3,20 \mathrm{~cd}$ \\
\hline
\end{tabular}




\begin{tabular}{llll}
\hline I $_{5}$ (LP 1) & 3,33 & 3,66 & $3,50 \mathrm{abc}$ \\
I $_{6}$ (LP 4) & 3,52 & 3,53 & $3,52 \mathrm{abc}$ \\
I $_{7}$ (TJA 3) & 2,88 & 3,35 & $3,11 \mathrm{~cd}$ \\
I $_{8}$ (LP 2) & 3,73 & 3,62 & $3,67 \mathrm{ab}$ \\
I $_{9}$ (BGR 3) & 3,80 & 3,80 & $3,80 \mathrm{a}$ \\
I $_{10}$ (BALAI 2) & 2,92 & 3,49 & $3,20 \mathrm{~cd}$ \\
I $_{11}$ (BGR 4) & 3,37 & 3,36 & $3,36 \mathrm{abc}$ \\
\hline RATAAN & $3,14 \mathrm{~b}$ & $3,32 \mathrm{a}$ & \\
\hline
\end{tabular}

Keterangan : Angka yang diikuti oleh huruf yang sama tidak berbeda nyata pada taraf $\alpha 5 \%$ menurut uji Duncan Multiple Range Test

Berdasarkan hasil pengukuran kadar $\mathrm{N}$ tanaman yang ditampilkan pada Tabel 7 diketahui kadar $\mathrm{N}$ tertinggi pada perlakuan I9 (BGR 3) yaitu 3,80 dan nilai kadar $\mathrm{N}$ terendah pada perlakuan $\mathrm{I}_{0}$ (kontrol) yaitu 1,88. Perlakuan I9 tidak berbeda nyata dengan perlakuan $\mathrm{I}_{8}$ (LP 2), $\mathrm{I}_{6}$ (LP 4), I5 (LP1) dan I 11 (BGR 4) serta berbeda nyata dengan $\mathrm{I}_{2}$ (BGR 1), I 1 (TJA 1), $\mathrm{I}_{10}$ (BALAI 2), I4 (LAB), I7 (TJA 3), I 3 (BALAI 3) dan I0 (Kontrol).

Pemberian kapur mampu meningkatkan kadar $\mathrm{N}$ tanaman seperti terlihat pada Tabel 6. Perlakuan pemberian kapur $\mathrm{K}_{1}$ (1 x Aldd) lebih tinggi yaitu 3,32 jika dibandingkan perlakuan $\mathrm{K}_{0}$ (tanpa kapur) yaitu 3,14. Hal ini dikarenakan pada pemberian kapur dapat meningkatkan $\mathrm{pH}$ tanah dan $\mathrm{pH}$ tanah tersebut merupakan $\mathrm{pH}$ yang optimum untuk pertumbuhan tanaman kedelai sehingga kadar hara tanaman dapat meningkat.

\section{Serapan N}

Hasil pengukuran serapan $\mathrm{N}$ tanaman kedelai dapat dilihat pada tabel di bawah ini :
Berdasarkan hasil pengukuran nilai serapan $\mathrm{N}$ yang ditampilkan pada Tabel 8 diketahui serapan $\mathrm{N}$ tertinggi ditunjukkan pada perlakuan I9 (BGR 3) yaitu 31,08 dan nilai serapan $\mathrm{N}$ terendah ditunjukkan pada perlakuan $\mathrm{I}_{0}$ (kontrol) yaitu 6,01. Perlkauan I9 (BGR 3) tidak berbeda nyata dengan I5 (LP1), I6 (LP 4), $\mathrm{I}_{8}$ (LP 2), I 4 (LAB), I I1 (BGR 4), I (TJA 1), $\mathrm{I}_{2}$ (BGR 1) dan $\mathrm{I}_{3}$ (BALAI 3) berbeda nyata dengan $\mathrm{I}_{10}$ (BALAI 2), I7 (TJA 3) dan $\mathrm{I}_{0}$ (Kontol) secara statistik.

Pemberian isolat Rhizobia mampu meningkatkan serapan nitrogen tanaman. Pada perlakuan isolat terbaik I9 (BGR 3), dimana rataan serapan $\mathrm{N}$ yang didapat 31,08 yang lebih tinggi dibandingkan dengan perlakuan tanpa pemberian isolat $\mathrm{I}_{0}$ yaitu sebesar 6,01. Pemberian isolat Rhizobia meningkatkan secara nyata serapan $\mathrm{N}$ pada tanaman kedelai. Tingginya serapan $\mathrm{N}$ tanaman merupakan tanda efektifitas tanaman tersebut. Hal ini didukung oleh Budiyanto (2002) yang menyatakan bahwa bakteri Rhizobia dapat mengubah $\mathrm{N}_{2}$ dari udara menjadi nitrogen yang difiksasi sehingga dapat digunakan tanaman serta dapat meningkatkan serapan nitrogen tanaman.

Tabel 8. Serapan N Tanaman Kedelai (Glycine max L.)

\begin{tabular}{lccc}
\hline \multicolumn{4}{c}{ SERAPAN N (mg/tanaman) } \\
\hline \multirow{2}{*}{ ISOLAT } & \multicolumn{2}{c}{ PENGAPURAN } & \multirow{2}{*}{ RATAAN } \\
\cline { 2 - 3 } & $\mathrm{K}_{0}$ (Tanpa Kapur) & $\mathrm{K}_{1}$ (Kapur 1 x Aldd) & \\
\hline I0 (Kontrol) & 5,21 & 6,81 & $6,01 \mathrm{c}$ \\
I $_{1}$ (TJA 1) & 17,69 & 22,37 & $20,023 \mathrm{ab}$ \\
I $_{2}$ (BGR 1) & 20,67 & 18,53 & $19,60 \mathrm{ab}$
\end{tabular}




\begin{tabular}{llll}
$\mathrm{I}_{3}$ (BALAI 3) & 20,62 & 15,89 & $18,25 \mathrm{abc}$ \\
$\mathrm{I}_{4}$ (LAB) & 19,81 & 25,93 & $22,87 \mathrm{ab}$ \\
$\mathrm{I}_{5}(\mathrm{LP} 1)$ & 15,41 & 35,97 & $25,69 \mathrm{ab}$ \\
$\mathrm{I}_{6}$ (LP 4) & 26,87 & 22,53 & $24,70 \mathrm{ab}$ \\
$\mathrm{I}_{7}$ (TJA 3) & 14,46 & 17,09 & $15,78 \mathrm{bc}$ \\
I $_{8}$ (LP 2) & 29,85 & 18,36 & $24,10 \mathrm{ab}$ \\
I $_{9}$ (BGR 3) & 32,00 & 30,16 & $31,08 \mathrm{a}$ \\
I $_{10}$ (BALAI 2) & 18,63 & 16,02 & $17,32 \mathrm{bc}$ \\
I $_{11}$ (BGR 4) & 25,34 & 18,18 & $21,76 \mathrm{ab}$ \\
\hline RATAAN & 20,54 & 20,65 & \\
\hline
\end{tabular}

Keterangan : Angka yang diikuti oleh huruf yang sama tidak berbeda nyata pada taraf $\alpha 5 \%$ menurut uji Duncan Multiple Range Test

Isolat Rhizobia yang infektif dalam menginfeksi akar tanaman sehingga dapat membentuk bintil akar. Isolat Rhizobia yang infektif dapat pula efektif dalam mengfiksasi $\mathrm{N}$ di udara. Hal ini pula yang didapati bahwa isolat I9 (BGR 3) efektif dalam penyerapan $\mathrm{N}$ yang telah di fiksasi oleh bakteri Rhizobia. Hal ini dikarenakan isolat $\mathrm{I}_{9}$ (BGR 3) merupakan isolat yang terbaik dalam menginfeksi akar serta efektif dalam memfiksasi nitrogen yang ada diudara. Dilam memfiksasi nitrogen diudara, bakteri Rhizobia menggunakan enzim nitrogenase untuk proses fiksasi $\mathrm{N}_{2}$ yang nantinya dapat mengubah $\mathrm{N}$ yang dapat diserap tanaman. Hal ini didukung oleh Purwaningsih (2008) yang menyatakan bahwa untuk memfiksasi nitrogen, bakteri Rhizobia menggunakan enzim nitrogenase, dimana enzim ini akan menambat gas nitrogen di udara dan merubahnya menjadi gas amoniak.

\section{Kadar P}

Hasil pengukuran kadar $\mathrm{P}$ tanaman kedelai dapat dilihat pada tabel di bawah ini :
Berdasarkan hasil pengukuran kadar P tanaman kedelai yang ditampilkan pada Tabel 9 diketahui kadar P tertinggi pada perlakuan $\mathrm{I}_{1}$ (TJA 1 ) dan $\mathrm{I}_{0}$ (kontrol) yaitu 0,29 dan terendah ditunjukkan pada perlakuan I10 (BALAI 2) yaitu 0,23. Hal ini dikarenakan isolat Rhizobia tidak dapat meningkatkan kadar $\mathrm{P}$, akan tetapi isolat Rhizobia hanya mampu memfiksasi nitrogen yang ada diudara yang akan diserap oleh tanaman.

Pemberian isolat Rhizobia tidak berbeda nyata dalam meningkatkan kadar fosfat tanaman. Faktor yang mempengaruhi tingginya kadar fosfat tanaman dipengaruhi oleh kandungan hara yang ada di dalam tanah. Isolat Rhizobia tidak mampu mengubah fostat yang ada didalam tanah untuk dapat di serap tanaman. Isolat Rhizobia tidak dapat meningkatkan kadar $\mathrm{P}$ dan tidak dapat mempengaruhi kadar $\mathrm{P}$ tersebut. Hal ini dikarenakan isolat Rhizobia hanya mampu memfiksasi nitrogen di udara. Isolat Rhizobia membutuhkan enzim nitrogenase dalam memfikasi $\mathrm{N}$ yang ada di udara. Isolat Rhizobia tidak mampu mengubah fostat yang ada didalam tanah untuk dapat di serap tanaman.

Tabel 8. Kadar P Tanaman Kedelai (Glycine max L.)

\begin{tabular}{|c|c|c|c|}
\hline \multicolumn{4}{|c|}{ KADAR P (ppm) } \\
\hline \multirow{2}{*}{ ISOLAT } & $\mathrm{PEN}$ & URAN & \multirow{2}{*}{ RATAAN } \\
\hline & $\mathrm{K}_{0}$ (Tanpa Kapur) & $\mathrm{K}_{1}$ (Kapur 1 x Aldd) & \\
\hline $\mathrm{I}_{0}$ (Kontrol) & 0,25 & 0,33 & 0,29 \\
\hline
\end{tabular}




\begin{tabular}{|c|c|c|c|}
\hline $\begin{array}{l}\text { Jurnal Pertanian } \\
\text { Vol.5, No.1. April }\end{array}$ & $75-87$ & & $56-4725$ \\
\hline $\mathrm{I}_{1}(\mathrm{TJA} 1)$ & 0,29 & 0,30 & 0,29 \\
\hline $\mathrm{I}_{2}$ (BGR 1) & 0,28 & 0,27 & 0,27 \\
\hline $\mathrm{I}_{3}(\mathrm{BALAI} 3)$ & 0,26 & 0,30 & 0,28 \\
\hline $\mathrm{I}_{4}(\mathrm{LAB})$ & 0,23 & 0,24 & 0,23 \\
\hline $\mathrm{I}_{5}(\mathrm{LP} 1)$ & 0,27 & 0,27 & 0,27 \\
\hline $\mathrm{I}_{6}(\mathrm{LP} 4)$ & 0,26 & 0,25 & 0,26 \\
\hline I7 (TJA 3) & 0,29 & 0,25 & 0,27 \\
\hline $\mathrm{I}_{8}$ (LP 2) & 0,26 & 0,26 & 0,26 \\
\hline $\mathrm{I}_{9}(\mathrm{BGR} 3)$ & 0,25 & 0,25 & 0,25 \\
\hline $\mathrm{I}_{10}$ (BALAI 2) & 0,21 & 0,26 & 0,23 \\
\hline $\mathrm{I}_{11}(\mathrm{BGR} 4)$ & 0,22 & 0,27 & 0,25 \\
\hline RATAAN & 0,26 & 0,27 & \\
\hline
\end{tabular}

\section{Serapan P}

Hasil pengukuran serapan $P$ tanaman kedelai dapat dilihat pada tabel di bawah ini :

Berdasarkan hasil pengukuran serapan $\mathrm{P}$ tanaman kedelai yang ditampilkan pada Tabel 10 diketahui serapan $\mathrm{P}$ tertinggi pada perlakuan I1 (TJA 1) 0,087 dan terendah ditunjukkan pada perlakuan I11 (BGR 4) yaitu 0,043. Hal ini dikarenakan isolat Rhizobia tidak dapat meningkatkan serapan $\mathrm{P}$, akan tetapi isolat Rhizobia hanya mampu memfiksasi nitrogen yang ada diudara yang akan diserap oleh tanaman.

Pemberian isolat Rhizobia tidak mampu meningkatkan serapan $\mathrm{P}$ tanaman kedelai. Hal ini dikarenakan tujuan utama bakteri Rhizobia hanya mampu memfiksasi nitrogen di udara. Hal ini pula ditunjukkan bahwa pemberian isolat terbaik I9 (BGR 3) tidak dapat meningkatkan serapan $\mathrm{P}$ tanaman akan tetapi isolat Rhizobia hanya mampu meningkatkan serapan $\mathrm{N}$ tanaman kedelai yang seperti di tampilkan pada Tabel 8 . Hal ini didukung oleh Purwaningsih (2008) yang menyatakan bahwa bakteri
Rhizobia mampu memfiksasi nitrogen yang ada diudara sebesar $70 \%$ sehingga dapat menghemat penggunaan pupuk kimia.

Pemberian kapur tidak berpengaruh nyata terhadap serapan $\mathrm{P}$, akan tetapi perlakuan pemberian kapur $\mathrm{K}_{1}$ (1xAldd) lebih tinggi yaitu 0.069 jika dibandingkan dengan perlakuan $\mathrm{K}_{0}$ (tanpa kapur) yaitu 0.067. Hal ini dikarenakan pemberian kapur tidak mampu menyediakan hara $\mathrm{P}$ untuk dapat diserap oleh tanaman kedelai. Pemberian kapur dolomit hanya meningkatkan $\mathrm{pH}$ tanah sehingga fosfat yang ada didalam tanah mudah terikat oleh $\mathrm{Ca}$ atau $\mathrm{Mg}$ yang terkandung pada kapur tersebut.

Pemberian isolat Rhizobia dan Pemberian kapur dolomit tidak dapat mempengaruhi serapan $\mathrm{P}$ secara nyata. Hal ini dikarenakan isolate Rhizobia tidak mampu menyediakan hara $\mathrm{P}$ untuk tanaman kedelai. Selain itu, hara $\mathrm{P}$ yang terdapat pada tanah dapat juga terikat oleh logam maupun $\mathrm{Ca}$ dan $\mathrm{Mg}$ yang berasal dari pemberian kapur dolomit pada tanah ultisol tersebut.

Tabel 10. Serapan P Tanaman Kedelai (Glycine max L.)

\begin{tabular}{ccc} 
& SERAPAN P $(\mathrm{mg} /$ tanaman $)$ & \\
\hline ISOLAT & PENGAPURAN & RATAAN \\
\hline
\end{tabular}




\begin{tabular}{|c|c|c|c|}
\hline & $\mathrm{K}_{0}$ (Tanpa Kapur) & $\mathrm{K}_{1}$ (Kapur 1 x Aldd) & \\
\hline $\mathrm{I}_{0}$ (Kontrol) & 0,071 & 0,101 & 0,086 \\
\hline $\mathrm{I}_{1}$ (TJA 1) & 0,083 & 0,091 & 0,087 \\
\hline $\mathrm{I}_{2}(\mathrm{BGR} 1)$ & 0,078 & 0,072 & 0,075 \\
\hline $\mathrm{I}_{3}(\mathrm{BALAI} 3)$ & 0,071 & 0,071 & 0,071 \\
\hline $\mathrm{I}_{4}(\mathrm{LAB})$ & 0,053 & 0,057 & 0,055 \\
\hline $\mathrm{I}_{5}(\mathrm{LP} 1)$ & 0,074 & 0,072 & 0,073 \\
\hline $\mathrm{I}_{6}(\mathrm{LP} 4)$ & 0,069 & 0,065 & 0,067 \\
\hline $\mathrm{I}_{7}$ (TJA 3) & 0,085 & 0,069 & 0,077 \\
\hline $\mathrm{I}_{8}$ (LP 2) & 0,069 & 0,068 & 0,068 \\
\hline $\mathrm{I}_{9}$ (BGR 3) & 0,064 & 0,063 & 0,063 \\
\hline I $_{10}$ (BALAI 2) & 0,042 & 0,070 & 0,056 \\
\hline $\mathrm{I}_{11}$ (BGR 4) & 0,049 & 0,038 & 0,043 \\
\hline RATAAN & 0,067 & 0,069 & \\
\hline
\end{tabular}

\section{SIMPULAN}

Isolat yang mampu hidup pada media YEM pH 3 infektif pada tanaman kedelai yang ditumbuhkan pada tanah masam. Isolat terbaik I9 (BGR 3) memiliki infektifitas yang tinggi pada tanaman kedelai yang ditumbuhkan pada tanah masam. Isolat yang mampu hidup pada media YEM pH 3 memiliki efektifitas tanaman kedelai yang ditumbuhkan pada tanah masam. Isolat terbaik I9 (BGR 3) memiliki efektifitas yang tinggi pada tanaman kedelai yang ditumbuhkan pada tanah masam. Isolat terbaik I9 (BGR 3) dan I5 (LP 1) infektif dan efektif terhadap pertumbuhan tanaman kedelai.

\section{DAFTAR PUSTAKA}

Harnowo, D. 2015. Agribisnis Kedelai : Antara Swasembada dan Kesejahteraan Petani. Liputan News. Universitas Gadjah Mada. Yogyakarta.

Sujana, I. P. dan I. N. L. S. Pura. 2015. Pengelolaan Tanah Ultisol dengan Pemberian Pembenah Organik Biochar Menuju Pertanian Berkelanjutan. Agrimeta, Jurnal
Pertanian Berbasis Keseimbangan Ekosistem. Vol.05 No.09 Hal 1-9. Hanafiah, S. A., T. Sabrina, H. Guchi. 2009. Biologi dan Ekologi Tanah. Program Studi Agroekoteknologi. Fakultas Pertanian. Universitas Sumatera Utara. Medan.

Widyasari, N. M., R. Kawuri., I K Muksin. 2013. Pengaruh pH Media Petumbuhan Terhadap Ketahanan Dari Rhizobium sp. Pada Tanah Yang Bersifat Asam. Jurnal Biologi XVII (2). Hal 56-60. ISSN:14105292.

Niste, M., R. Vidican., I. Rotar dan R. Pop. 2013. The Effect of $\mathrm{pH}$ Stress on the Survival Rhizobium trifolii and SinoRhizobium meliloti in Vitro. University of Agriculture Sciences and Veterinary Medicine ClujNapoca. Bulletin UASMV series Agriculture 70(2) Hal. 449-450.

Soepardi, G. 1983. Dasar - Dasar Ilmu Tanah. Institut Pertanian Bogor. Bogor.

Purwaningsih, O., D. Indradewa, S. Kabirun, dan D. Shiddiq. 2005. Tanggapan Tanaman Kedelai Terhadap Inokulasi Rhizobium 
Universitas Gadjah Mada, Yogyakarta.

Yuwono, T. 2006. Bioteknologi Pertanian. Gadjah Mada University Press. Yogyakarta.

Hanafiah, S. A. 1991. Inokulum Rhizobium : Bioteknologi untuk Meningkatkan Produksi

Pertanian. Makalah Seminar Nasional Pemantapan Pengembangan Agribisnis Terpadu Dalam PJPT II. Fakultas Pertanian Universitas Sumatera Utara. Medan.

Surtiningsih T, Farida dan T Nurhayati. 2009. Biofertilisasi Bakteri Rhizobia pada Tanaman Kedelai (Glycine max (L) Merril). Berkala Penelitian Hayati 15, 31-35.

Budiyanto, M. A. K. 2002. Mikrobiologi Terapan. Universitas Muhammadiyah Malang Press. Malang.

Mukhlis, Sarifudin dan H. Hanum. 2011. Kimia Tanah: Teori dan Aplikasi. USU Press. Medan. 287 p 